\title{
THE VALUATION OF HOPE VALUE FOR REAL ESTATE DEVELOPMENT
}

\author{
Małgorzata Renigier-Biłozor, PhD \\ Faculty of Geodesy, Geospatial and Civil Engineering \\ University of Warmia and Mazury in Olsztyn \\ e-mail:malgorzata.renigier@uwm.edu.pl
}

\author{
Maurizio d'Amato, FRICS, REV Associate Professor \\ Property Valuation and Investment DICATECh \\ Technical University Politecnico di Bari \\ e-mail:madamato@fastwebnet.it
}

\begin{abstract}
In the valuation of a property subject to development, the valuer may consider the potential aspect of the value of both land to be improved and a building to be refurbished. These kinds of valuations are complex, especially when a prudent assessment of value is required. In general terms, all properties may have potential development which, in some cases, can be termed "hope". In particular, uncertainty regarding the change in the legal framework may create expectations as to the uncertain variation of property value in the future. In these cases, it may be necessary to deal with hope value or future value, trying to reach the value of a property subjected to uncertain changes. Hope value is the difference between the existing use value and the price that the market might pay for future transformation.

The main aim of the paper is the elaboration of a methodology to determine the hope value. In this work, a real option model for the valuation of hope value in the real estate market will be applied to a small sample of residential properties located in Olsztyn that are subject to possible transformation. The possibility of a transformation may create expectations and may influence the value of the property. Although the applications of these methods to real estate valuation are fairly recent, the International Valuation Standards have included real option theory in the income approach as a valuation method since 2011.
\end{abstract}

Key words: real estate development, option theory, hope value.

JEL Classification: $C 15, C 18, D 80, R 20$.

Citation: Renigier-Biłozor M., d'Amato M., 2017, The Valuation of Hope Value for Real Estate Development, Real Estate Management and Valuation, vol. 25, no. 2, pp. 91-101.

DOI: 10.1515/remav-2017-0016

\section{Introduction ${ }^{1}$}

In the valuation of a property for development, one of the most challenging aspects is to define the potential aspect of the value of both the land to be improved and a building to be refurbished. These kinds of valuations are complex and difficult, especially when a prudent assessment of value is required concerning, for example, the determination of mortgage lending value (D'AMATO 2010). According to European Valuation Standards, the mortgage lending value can be defined as "...an assessment of the long term value of the security, available to guide internal banking decision..." (EVA2 para

\footnotetext{
1 The authors are grateful for the valuable comments of the two anonymous referees of the review. The study was prepared as a result of the implementation of research project No. UMO-2014/13/B/HS4/00171, financed from the funds of the National Science Centre.
} 
5.1). Defining long-term value for an underdeveloped property is difficult, especially for properties whose value is influenced by uncertain changes in the regulatory framework. Furthermore, the European Central Bank asked for the determination of a specific basis of value called "hope value", defined as follows: "hope value refers to the potential increase in value achieved through investing in improving the aspect of a property, e.g. completing the development of a partially completed office building" (Asset Quality Review, Manual II Phase, p. 147). The general assumptions take into account the application of the proposed methodology to every kind of underdeveloped property. In our work we will propose a model applying it to the residential sector.

Several professional documents address the concept of hope value. In the RICS (2012) document of financial viability, hope value is defined as: “(...) Any element of the open market value of a property in excess of the current use value, reflecting the prospect of some more valuable future use or development..."( Appendix F Glossary Terms, p. 43). Furthermore, The European Valuation Standards 1 (EVS 2012 point 5.4.4) describe hope value as follow: "Hope value is used to describe the price (...) which the market is willing to pay in the hope of a higher value use or development opportunity being achievable than is currently permitted under development control (...) the time scale and any other associated factors in bringing it about. Fundamentally, it will allow for the possibility that the envisaged use may not be achieved. While descriptive of that uplift, it does not exist as a separate value but helps explain the market value of the property which must be judged from the available evidence just as much as any other part of the valuation". The concept refers to the potential development of a property, either building or land (D'AMATO et al. 2016). In general terms, all properties may have potential development (D'AMATO et al. 2012). Hope value can also be defined as a market sensitive pricing of a property reflecting the difference between current and potential values of the property subject to development.

All the definitions previously cited require an assessment of the level and scope of that potential, also defined as "hope". Due to the main object of study, i.e. apartments for development, the concept may be considered as the difference between the value in existing use and the value that the market may pay for future transformation. Hope value is, therefore, the difference between the existing use value and the price that the market might pay for the property with the hope of a more valuable use. In this case, the property value should reflect the value of potential economically viable changes to the property which, inter alia, are legally permissible at the date of valuation. In uncertain contexts, it may occur that market value reflects an even more valuable use which is not legally permissible at the date of valuation but which may become so in the future. For this reason, the market value would include an additional element over and above the value for highest and best use to reflect an amount that a willing purchaser would pay at the date of valuation in the hope that a more valuable use which is not legally permissible becomes so in the future. MOREOVER, COSTELLO et al. (2011) highlighted that the application of the real option in the valuation of hope value is a more reliable and sophisticated opportunity to reflect the value than the traditional techniques, such as DCF or residual.

The traditional techniques rely on the causal relationship between the dependent variable or value and independent variables, as property characteristics or rent. Unfortunately, when dealing with uncertain phenomena, such as a probable change in the legal framework, it may be advisable to deal with a casual approach rooted on a probabilistic relationship instead of deterministic one. The main aim of the paper is the elaboration of a methodology to determine the hope value for underdeveloped residential properties. In this work, the application of a real option model for the valuation of hope value in the residential real estate market is proposed. Many contributions are provided to analyze the nature of the real estate option. It is possible to classify two possible methodological approaches to the real option for real estate market analysis and valuation, as follows:

- the first group of contributions focused on the binomial modelling that was applied by the work of Titman. In this case, the main problems are the forecast of the future state of the world and the necessity of having only two possible outcomes,

- the second group of contributions focused on Black Scholes derived modelling. This second group of contributions is based on the hypothesis that share prices are normally distributed, and future share values follow a specific distribution instead of binomial outcomes.

The second possible approach is based on continuous compound financial mathematics, and this is a much greater limitation than the problem raised in the application of binomial modelling from the authors' point of view. For this reason, the authors propose their own elaboration and application based on Titman's work, strictly related to the binomial process. It is important to stress that the application of continuous compound methodology would be better fit for the financial market, where 
transaction costs are low and frictionless. In this case, the return on a share may be continuous, both in terms of income and in terms of capital gain. The same consideration seems quite difficult to refer to the direct real estate market.

In order to analyze and explore the contribution of the real option theory to solving this kind of appraisal problem, a simulation on the basis of 13 apartments to be refurbished from the Olsztyn residential market was conducted.

The paper is structured in the following way. First, there is an explanation of the needs to determine hope value in Section 1. Section 2 resents a literature review about real option theory applied to real estate investment and valuation. Section 3 presents the methodology of the research and the application of the proposed solutions to a real case. Finally, Section 4 presents conclusions and future directions of research concerning the achieved results.

\section{Literature review}

Option theory was introduced by the pioneering scientific work of Nobel Prize winners BLACK AND SCHOLES (1973). Later, an extensive application of these methods to investment was defined as the "real option" (MYERS 1977). Option pricing is a field of studies inside real options. Although the applications of these methods to the real estate markets are recent, in the last decade, several professional documents have provided an introduction to the real option for valuation purposes. In particular, a RICS document on the applications of the real option in property explain, in a clear way, several possible applications of the real option in real estate investment (PATEL et al. 2005). Real option theory was introduced in the International Valuation Standard in 2011. In particular, IVS 2013, following previous international valuation standards of 2011, provides this definition of the income approach: "Methods that fall under the income approach include: Income capitalisation, where an all-risks or overall capitalisation rate is applied to a representative single period income; Discounted cash flow, where a discount rate is applied to a series of cash flows for future periods to discount them to a present value; Various option pricing models" (IVS 2013, Framework, paragraph 60). As one can see, in the most important professional valuation standard "...various option pricing models..." are specifically quoted as a further valuation methodology. It is important to stress the distinction between option pricing and the property option. Considering this, "option pricing" is a set of mathematical models to analyse real estate valuation and investment problems, while the "property option" is a contract used by developers to have the opportunity to buy a piece of space at a specific price.

Real option theory has been applied in several aspects of property valuation. Recently, WOMACK (2015) provided a recent review of the work on real option theory to value urban land. BRENNAN AND SCHWARTZ (1985) proposed real options as a tool for real investment decisions. They used the example of mineral extraction to demonstrate that the standard net present value (NPV) analysis led to an unfair valuation of the investment. MCDONALD AND SIEGEL (1986) assert that the standard NPV investment decision rule can be considered significant only if the variance of the present value of the costs and future benefits are both equal to zero. In a real estate context, BRUECKNER AND VINTAGE (1980) and WHEATON (1982) observed the relationship between the assumption of zero demolition cost in models of urban spatial growth and the possibility of the building being abandoned before redevelopment occurred. Titman (TITMAN 1985) applied this method for the first time to the valuation of vacant land. Later real option models have been applied in the fields of real estate finance (KUTNER AND SEIFERT 1989) and lease contract contingencies (BUETOW et al. 1998).

A binomial option model was applied to determine the optimal condition of real estate investment (WILlIAMS 1991). Williams demonstrated that negative or sufficiently small, yet positive, net cash flows can result in deciding to abandon a property. He concluded that underdeveloped property is abandoned earlier than developed property because it is more expensive. CAPOZZA AND SICK (1994) combined option theory with monocentric urban economic theory. GRENADIER (1995) uses real option theory to explain the cyclical behavior of the real estate market, while HoLLAND (HOLLAND et al. 2000) explained cyclical dynamics or the real estate market using a general equilibrium model obtained using the real option. In this context, the waiting option shows an important role in the decisional process of the market player. In the real estate literature applied for valuation, the greatest part of contributions relies on binomial modelling. A different view on WILLIAMs's (1991) and QUIGG's (1993) approaches is provided analyzing the effect of scale elasticity and unit construction cost on the real estate project. The work showed a positive relationship between the option of waiting and the volatility of unit rental and unit construction costs (TIEN FOO SING 2001). SOMERVILLE (2001) analyzed 
whether the development option can be considered a compound option, that is an option underlying another option. He demonstrates that obtaining building permits concludes the development process, and, as a consequence, there is no evidence for the analysis as a compound option. CUNNINGHAM (2007) demonstrates a negative correlation between real estate development and price uncertainty, and a positive correlation between property prices and uncertainty. CLAPP and SALAVEI (2010), CLAPP, JOU and LEE (2012), and CLAPP, SALAVEI and WONG (2012) included the redevelopment option value as separate from the value of the property inside a hedonic model. Furthermore, GROVENSTEIN et al. (2011) improved QUIGG'S (1993) work using empirical data to calculate development cost elasticity. They also demonstrate that elasticity cost has an important impact on the option value.

\section{Methodology of the research and case study}

\subsection{Method of the research}

The paper proposes an application of real option theory to underdeveloped apartments in order to face this challenging task, and also provides a comparison between the apartment price and the estimated value using the real option in order to define both the validity of the application of the real option to the real world and to demonstrate that this method may have the potential to address the professional problems of hope value determination. The traditional methodologies, such as market, income and cost, are normally based on a dominant causal relationship between value and technical or economic characteristics of the property. The market approach is based on a direct causal relationship between price and characteristics, the income approach is based on a direct causal relationship between price and rent, while the cost approach is based on a direct causal relationship between cost and value. Appraising hope value means dealing with an uncertain event and, in this specific case, the methodologies should switch from a causal relationship between price and characteristics to a casual relationship. Therefore, the real option theory is an interesting direction of research. Cox et al. (1979) proposed the binomial model. Real property options can be defined as " (...) opportunities from the holder to benefit from the upside, while only suffering loss premium as a downside $(. .$.$) "(PATEL et al. 2005; p. 7). Furthermore, this kind of option can be exercised at any time (American$ ption) or at a certain moment (European option). A property to be refurbished may be seen as an "American call option" that the owner may buy to increase its value. In the presence of a changing and uncertain legal framework, the exercise price is the cost of the refurbishment, while the market price depends on the level of the price of the building before and after the refurbishment has taken place and interest rates equivalent to a risk-free asset. In this context the property may have a value, a hope value, because of the increase of the market value of the property (growth option) as a consequence of the refurbishment. It may also have a hope value because the owner of the property may decide to postpone the refurbishment and wait for a future attractive level of prices (deferring option). In both cases, the owner deals with the call option. The call option has been defined as an opportunity "... for the holder to benefit from the upside while only suffering the loss of premium (initial payment for the option, which equals unrecoverable initial costs for a real option) as a downside..."(PATEL et al. 2005). Both the growth option and the deferring option can be calculated with the same pay-off algorithm described in Formula 1 below:

$$
\max \left(P_{t}-K_{t} ; 0\right)
$$

In general terms, the value of the call option is the difference between the market value $P_{t}$ of the building unit at time $t$, and the exercise price or the construction cost at time 0 or $K t$. If this difference is lower than 0 , then the value of the call (either the growth option or deferring option) is equal to 0 . On the other hand, the more this difference increases positively, the more the call option value rises. In the application proposed, there is a causal relationship between the cost of the refurbishment and the property value. Therefore, the behaviour of the owner of the property will be modelled as in Formula 2 below:

$$
\max (P 1-K t(1+i))
$$

In Formula $1, P_{1}$ is the price of the property at time 1 after the refurbishment, while $K t$ is the value of the cost of the refurbishment paid at time 0 and reported at time 1 using the risk free rate. For the first order condition, the maximization problem will be solved as in the following Formula 3 below: 


$$
\frac{\Delta \mathrm{P}}{\Delta q}=\frac{\Delta \mathrm{Kt}}{\Delta q}
$$

In this formula, the first derivative of $P$ per square metre $(\Delta \mathrm{P} / \Delta \mathrm{q}) q$ is equal to the first derivative of cost $K_{t}$ per square meter. Both price and cost are convex increasing functions. They represent the behaviour of the owner of a property who wants to maximize its value by refurbishing his home. In particular, dealing with hope value, there are sources of uncertainty in the legal framework that may or may not create advantages for the property owner. Because of the direct relationship between property price and property rent in Relationship 2, another maximization function is embedded. A property owner who is interested in investing money will be interested in maximizing Function 4 as well. In other words, the owner may also be interested in increasing the difference between the rent and the management costs of the property. In this case, the function representing the behavior of the property owner is indicated in Formula 4:

$$
\max (R l-K g)
$$

It is evident that, as the rent is proportional to value, Function 4 will be considered included in Function 2. Both rent and cost are convex increasing functions. They represent the behaviour of the owner of a property who wants to maximize the rent of the property by refurbishing his home trying to achieve a highest and best use for their property. This will be possible if there is only one constant cost for the refurbishment, and one price and only one rent for the property in the specific market segment. The conditions in Formulas 2 and 4 demonstrate that both the price and the rent of the building are increasing and the convex function as the cost of the refurbishment. The proposed application will have only two dates. The former is time 0 . In this period, the property is not refurbished and has one price in the specific market segment. The latter is time 1 - after the refurbishing process. The hypothesis is coherent with the nature of the direct real estate market whose imperfections create an enormous distance with the financial assets (RENIGIER-BILOZOR et al. 2017). At this time, i.e. 1 , the market price of the refurbished building can only assume two values at date 1 or $p_{h}$ and $p_{l}$. These are acronyms that mean $\mathrm{p}$ high and $\mathrm{p}$ low. As a consequence, the value of the refurbished property will have two possible values, i.e. $p_{\mathrm{h}}$ and $p_{l}$, following the market behaviour of the price per square meter of the refurbished building. In a similar way, we will have an $R_{l}$ and a $R_{h}$. After the refurbishment, the property may have two different rents: the former high and the latter low. This is important because it is possible that the owner of the property decides to refurbish the property either for using it directly or renting it out. It is also assumed that a risk free asset exists, having a return of $R_{f}$. This is a generally recognized assumption. A perfect market hypothesis is also assumed (no transaction cost, no taxes, no short selling restrictions). In this regard, TITMAN (1985) states: "The assumption of frictionless markets, generally assumed in models of security prices, is considered by some to be less realistic when applied to real estate markets. However, it should be noted that securities represent indirect claims on factories and equipment that are probably much less liquid than real estate. Yet we can price these assets as if they were perfectly liquid because the securities are traded on (almost) frictionless markets. Similarly, a large fraction of real estate is held by publicly traded firms. If the real estate investments of these firms are chosen in a manner consistent with value maximization, then real estate prices will be determined in equilibrium as if markets were really frictionless" (TITMAN 1985 p. 507). There are only two investments building refurbishment and risk free assets. The condition may seem unreliable, but owners or the developer, having a property to refurbish in their portfolio, see the world in the same way, because of the specialization of their activity. Without riskless arbitrage, the price of vacant land is determined by these investments. The first stage is the calculation of state prices. These state prices are relevant to reaching the final results. They must satisfy two conditions. The former of these is indicated in Formula 5 below:

$$
\left(\mathrm{P}_{0}+\mathrm{R}_{0}\right)(1+\mathrm{i})=\mathrm{s}_{\mathrm{h}} \mathrm{P}_{\mathrm{h}}+\mathrm{s}_{\mathrm{l}} \mathrm{P}_{\mathrm{l}}+\mathrm{s}_{\mathrm{l}} \mathrm{Rl}+\mathrm{s}_{\mathrm{h}} \mathrm{Rh}
$$

In Formula $5, P_{0}$ is the price of the property at time 0 before the refurbishment process, $R_{0}$ is the rent of the not refurbished property, $P_{h}$ is the price of the property at time 1 , decreased by the cost of the refurbishment for the high states of nature, while $P_{l}$ is the price of the property decreased by the cost of the refurbishment for the low state of nature. In a similar way, $R_{h}$ is the rent for the high state of nature after the refurbishment process, and $R_{l}$ is the rent of the property for the low state of nature. In this case, it is possible for the owner to also refurbish the property to make a profit or rent it. This is 
the reason why, in Formula 6, starting from the previous application to vacant land (TITMAN 1985), it is possible to provide a forecast of the rent provided by the property.

In this paper, we propose a new model based on real option theory considering a property to be refurbished. While in Titman's original model the estimation of the vacant land was based on the future price of the improvements and only one rent, in the author's perspective, the rent will have two states of the world in the application to the building refurbishment, i.e.: the former optimistic $\left(R_{h}\right.$ or high rent) and the latter pessimistic $\left(R_{l}\right.$ or low rent). In the second condition, using the appropriate financial mathematics of real estate (compound not continuous), the two states of price will account for the following sum:

$$
1=\mathrm{s}_{\mathrm{h}}\left(1+\mathrm{R}_{\mathrm{f}}\right)+\mathrm{s}_{1}\left(1+\mathrm{R}_{\mathrm{f}}\right)
$$

In this case $s_{h}$ and $s_{l}$ are the pseudo-probabilities, and $R_{f}$ is the risk-free rate. The authors propose the COX, Ross and RUBINSTEIN model or binomial approach (COX et al. 1979). In Formula 6, sh are the pseudo probabilities of the high state of nature, while $s_{l}$ are the pseudo probabilities in the low state of nature. The sum of these pseudo probabilities at time 1 must be equal to 1 . The assumption on which this method is based starts from TITMAN's original model (1985) as further modified by D'AMATO et al. (2016). In fact, $D^{\prime}$ Amato et al. proposed the determination of an algorithm to define the hope value based on Titman's original paper using the price per square meter instead of the original price per unit; furthermore, the rent in that model has been eliminated, which seems coherent with the appraisal problem. On the other hand, the present model has both price and rent because of the payoff algorithms in Formulas 1 and 2. The valuation is based on the assumption that a risk free asset exists and is coincident with the Polish government bond at 10 years, equal to 0.03 . The combination of Formula 5 and Formula 6 will allow for the defining the pseudo-probabilities as follows:

and

$$
s_{h}=\frac{P_{0}(1+R f)^{2}-R_{l}-P_{l}}{(1+R f)\left(R_{h}-R_{l}+P_{h}-P_{l}\right)}
$$

$$
S_{l}=\frac{P_{0}(1+R f)^{2}-R_{h}-P_{h}}{(1+R f)\left(R_{l}-R_{h}+P l-P_{h}\right)}
$$

The determination of pseudo probabilities $s_{h}$ and $s_{l}$ will allow the appraiser to determine the value of the property to be refurbished using Formula 9 (TITMAN 1985) below:

$$
V_{1}=\pi\left(P_{h}\right) s h+\pi\left(P_{l}\right) s l
$$

This is the value of the property to be refurbished at date 0 , which will be refurbished at time 1 , based on two pseudo probabilities and two different states of prices $P_{h}$ and $P_{l}$. If the property value exceeds the cost of refurbishment and the price of the building at date 0 , the owner may try to refurbish the house (growth option) or he may be interested in waiting for more profits (deferring option). Hope value occurs (D'AMATO et al. 2016) when the current use of the property may have a: building price inferior to the excess of value guaranteed by the refurbishment occurring in an uncertain environment at time 1 as indicated in Formula 10 below:

$$
\pi\left(P_{0}\right)<\pi\left(P_{h}\right) s h+\pi\left(P_{l}\right) s l
$$

In Formula 10, the value of the building at date 0 is less than the present value of the building at date 1 after the refurbishment. Attention will be focused on Formula 10, and this will provide an estimation of the hope value as the difference between the price at time 0 and the price of the property at time 1 using real option theory.

\subsection{Application of the author's model for determining hope value}

The model proposed for the valuation of the hope value of apartments using Titman's model has been tested on 13 transactions of underdeveloped residential apartment prices in the Olsztyn property market. In this specific case, the application of the author's model will be defined and will be applied using a simple real option monoperiodal model that is closer to the real set of information of the appraiser operating in the direct real estate market. In fact, it seems quite unrealistic to suppose that the appraiser will be able to provide a forecast related to more than two or three periods. It is wellknown that uncertainty in valuation has several different causes; among others, there is also input availability or the "lack of market data" (Technical Information Paper 4, Valuation Uncertainty para. 22). This kind of model is suitable for the valuation problem considered in this case. Further 
information was provided by valuers in the area who were able to define a forecast for the value (D'AMATO 2015; D'AMATO 2016) of the properties after the refurbishment at time 1. One of the reasons for the choice of the sample is the possibility to easily reach real estate market information in the residential sector. The list of the residential apartments (in condominiums) to be refurbished are indicated below (Tab.1).

Table 1

Sample of residential apartments for renovation to be appraised

\begin{tabular}{ccccc}
\hline Obs. & Location & $\begin{array}{c}\text { Usable dwelling } \\
\text { space (in sq. m) }\end{array}$ & $\mathbf{P}_{\mathbf{0}}$ (in PLN) & $\mathbf{R}_{\mathbf{0}}$ (in PLN) \\
\hline 1 & Kosciuszki & 79.17 & 379630.00 & 22116.93 \\
\hline 2 & Glowackiego & 60.19 & 317669.00 & 14572.72 \\
\hline 3 & Zurawia & 53.02 & 211098.00 & 10861.89 \\
\hline 4 & Lesna & 122.12 & 485857.00 & 39801.35 \\
\hline 5 & Sikorskiego & 62.37 & 255403.00 & 13938.95 \\
\hline 6 & Kosciuszki & 100.90 & 216000.00 & 20670.78 \\
\hline 7 & Kosciuszki & 116.17 & 498298.00 & 34616.80 \\
\hline 8 & Wyspianskiego & 127.40 & 181800.00 & 20167.93 \\
\hline 9 & Morenowa & 73.11 & 324074.00 & 17020.01 \\
\hline 10 & Osiedle nad dolina & 62.75 & 235313.00 & 11686.56 \\
\hline 11 & Mroza & 67.50 & 300000.00 & 18856.80 \\
\hline 13 & Zbicza & 75.86 & 276423.00 & 14128.17 \\
\hline
\end{tabular}

Source: Own elaboration

In Table 1, the first column indicates the number of the observation. The second column shows the different locations within the city of Olsztyn. The third column is the usable dwelling space, while the fourth column $\left(\boldsymbol{P}_{0}\right)$ is the transaction price at time 0 without refurbishment. Finally, the fifth column $\left(\boldsymbol{R}_{\boldsymbol{0}}\right)$ indicates the rent for the property without refurbishment in its present condition. The transactions in the sample took place in 2016. In the following Table (2), the first column indicates the number of the observation. The second column shows the different locations in Olsztyn. The third column $\left(\boldsymbol{P}_{l}\right)$ is the state price after refurbishment, supposing an increment of the value equal to the simple risk-free rate (in this case equal to 0.03 ), the fourth column $\left(\boldsymbol{R}_{l}\right)$ indicates the lower increase of the rent at the risk free rate. The fifth column $\left(\boldsymbol{P}_{h}\right)$ is the increase of the price after refurbishment in the higher state of the world, while the sixth column $\left(\boldsymbol{R}_{h}\right)$ is the increase of the rent in the higher state of the world. The seventh column $\left(K_{t}\right)$ is the price of the call at the higher state price at time 1 . Therefore, at time 1 , the property may have a higher price and rent after the refurbishment, or may have the price and rent of the past, increased at the risk-free rate.

Table 2

Sample of 13 observations

\begin{tabular}{ccccccc}
\hline Obs. & Location & $\mathbf{P}_{\mathbf{l}}(\mathbf{i n} \mathbf{P L N})$ & $\mathbf{R}_{\mathbf{l}}(\mathbf{i n} \mathbf{P L N})$ & $\mathbf{P}_{\mathbf{h}}(\mathbf{i n} \mathbf{P L N})$ & $\mathbf{R}_{\mathbf{h}}(\mathbf{i n} \mathbf{P L N})$ & $\mathbf{K}_{\mathbf{t}}(\mathbf{i n} \mathbf{P L N})$ \\
\hline 1 & Kosciuszki & 391018.90 & 22780.44 & 472000.00 & 28400.00 & 67446.46 \\
\hline 2 & Glowackiego & 327199.07 & 15009.90 & 423000.00 & 18720.00 & 51500.00 \\
\hline 3 & Zurawia & 217430.94 & 11187.75 & 294000.00 & 14000.00 & 61800.00 \\
\hline 4 & Lesna & 500432.71 & 40995.39 & 674000.00 & 51000.00 & 208060.00 \\
\hline 5 & Sikorskiego & 263065.09 & 14357.11 & 333000.00 & 18100.00 & 51500.00 \\
\hline 6 & Kosciuszki & 222480.00 & 21290.90 & 299000.00 & 25200.00 & 51500.00 \\
\hline 7 & Kosciuszki & 513246.94 & 35655.31 & 677000.00 & 44500.00 & 103000.00 \\
\hline 8 & Wyspianskiego & 187254.00 & 20772.97 & 468000.00 & 26000.00 & 236900.00 \\
\hline 9 & Morenowa & 333796.22 & 17530.61 & 410000.00 & 21000.00 & 51500.00 \\
\hline 10 & Osiedle nad dolina & 242372.39 & 12037.16 & 312000.00 & 15000.00 & 52934.79 \\
\hline
\end{tabular}




\begin{tabular}{llllllc}
\hline 11 & Mroza & 309000.00 & 19422.50 & 377000.00 & 24000.00 & 49568.75 \\
\hline 12 & Zbicza & 284715.69 & 14552.01 & 484000.00 & 18000.00 & 108150.00 \\
\hline 13 & Lesna & 547127.76 & 40995.39 & 674000.00 & 51000.00 & 63860.00 \\
\hline
\end{tabular}

Source: Own elaboration.

The calculations of pseudo-probabilities based on Formulas 7 and 8 per observation are indicated in Table 3. Using Formulas 7, 8 and 9, it is possible to provide the calculation of pseudo probabilities per observation as indicated in the table below:

Calculation of pseudo probabilities

Table 3

\begin{tabular}{|c|c|c|c|c|}
\hline Obs. & $\mathbf{s}_{\mathrm{h}}$ & $\Pi\left(P_{h}\right)($ in $P L N)$ & $\mathrm{s}_{1}$ & $\Pi\left(\mathrm{P}_{1}\right)($ in PLN) \\
\hline 1 & 0.1392 & 434918.00 & 0.8317 & 348317.34 \\
\hline 2 & 0.1002 & 391720.00 & 0.8707 & 292208.97 \\
\hline 3 & 0.0839 & 248000.00 & 0.8870 & 168618.69 \\
\hline 4 & 0.0859 & 523000.00 & 0.8850 & 339428.10 \\
\hline 5 & 0.1097 & 301100.00 & 0.8612 & 227422.20 \\
\hline 6 & 0.0883 & 274200.00 & 0.8826 & 193770.90 \\
\hline 7 & 0.0926 & 621500.00 & 0.8782 & 448902.25 \\
\hline 8 & 0.0212 & 264000.00 & 0.9497 & - 21973.03 \\
\hline 9 & 0.1284 & 381000.00 & 0.8424 & 301326.83 \\
\hline 10 & 0.1021 & 275607.00 & 0.8688 & 203016.55 \\
\hline 11 & 0.1318 & 352875.00 & 0.8391 & 280297.50 \\
\hline 12 & 0.0430 & 397000.00 & 0.9279 & 194267.70 \\
\hline 13 & 0.1251 & 663000.00 & 0.8457 & 526123.15 \\
\hline
\end{tabular}

Source: Own elaboration.

The first column contains the number of the observation. In the second $\left(\boldsymbol{s}_{h}\right)$ and the fourth $\left(\boldsymbol{s}_{l}\right)$ columns, the pseudo probabilities are calculated adapting Titman's model with some variations to the specific case. In this work, we will use the author's model in order to differentiate it from Titman's original model. It is worth mentioning that, among several different methods, Titman selected risk neutral valuation in his original work. The other methods are portfolio replica and Arrow Debreu prices. We followed the same risk neutral method adopted by Titman in his work. The third $\left(\Pi\left(\boldsymbol{P}_{h}\right)\right)$ and the fourth columns $\left(\Pi\left(P_{l}\right)\right)$ indicate the price and the rent of the property after the refurbishment. In Table 3, the pseudo probabilities of the first observation have been obtained combining Formulas 7 and 8 as follows:

$$
\begin{aligned}
& s h_{01}=\frac{(379,630.00 P L N+22,116.93 P L N)(1+0.03)^{2}-22,780.44 P L N-391,018.90 P L N}{(1+0.03)(28,400.00 P L N-22,780.44 P L N+472,000 P L N-391,018.90 P L N)}=0.13 \\
& s l_{01}=\frac{(379,630.00 P L N+22,116.93 P L N)(1+0.03)^{2}-28,400.00 P L N-472,000.00 P L N}{(1+0.03)(22,780.44 P L N+391,018.90 P L N-28,400.00 P L N-472,000.00 P L N)}=0.83
\end{aligned}
$$

Starting with the results in Table 3, it is possible to calculate the hope value per observation. In the following table (4), the first column is the number of the observations, the second column $\left(\mathrm{V}_{1}\right)$ is the value at time 1 of a refurbished property observing the growth of the price and rent, while the third column $\left(\mathrm{V}_{0}\right)$ indicates the value of a not refurbished property or in its current use. The difference between the value of the property at the time after the transformation and the value at its current use is indicated in the fourth column $\left(\mathrm{V}_{\mathrm{H}}\right)$. This column indicates the quantification of hope value. Therefore, the methodological relationship between hope value and real option modelling is more evident. It is possible to use the flexible casual approach of real option theory based mainly on the binomial stochastic process to address the effect of uncertain events on the property value. The different events that can be modelled at even more than one time are a way to model the uncertainty of future events diminishing valuation uncertainty. In fact, a further source of valuation uncertainty is also the "choice of valuation model" (IVSC, Technical Information Paper 4, Valuation Uncertainty, 
para 17). In the final columns $\left(V_{H} / V_{1}\right.$ and $\left.V_{H} / P_{0}\right)$ these ratios are two different hope value ratios. The former result $\left(V_{H} / V_{1}\right)$ is the ratio between the hope value and the perspective value of the property calculated by the real option theory, while the latter $\left(V_{H} / P_{0}\right)$ is the ratio between the hope value and the primary value of the property. In order to differentiate between these issues, we propose the following division: perspective hope ratio for the first and primary hope ratio for the second.

Table 4

Determining Hope Value and the Hope Value Ratio using the author's model

\begin{tabular}{cccccc}
\hline Obs. & $\mathbf{V}_{\mathbf{1}}$ (in PLN) & $\mathbf{V}_{\mathbf{0}}$ (in PLN) & $\mathbf{V}_{\mathbf{H}}$ (in PLN) & $\mathbf{V}_{\mathbf{H}} / \mathbf{V}_{\mathbf{1}}$ & $\mathbf{V}_{\mathbf{H}} / \mathbf{P}_{\mathbf{0}}$ \\
\hline 1 & 350224.58 & 314148.00 & 36076.58 & $10 \%$ & $10 \%$ \\
\hline 2 & 293665.28 & 267669.00 & 25996.28 & $9 \%$ & $8 \%$ \\
\hline 3 & 170366.26 & 151098.00 & 19268.26 & $11 \%$ & $9 \%$ \\
\hline 4 & 345311.60 & 283857.00 & 61454.60 & $18 \%$ & $13 \%$ \\
\hline 5 & 228878.52 & 205403.00 & 23475.52 & $10 \%$ & $9 \%$ \\
\hline 6 & 195227.21 & 166000.00 & 29227.21 & $15 \%$ & $14 \%$ \\
\hline 7 & 451814.87 & 398298.00 & 53516,87 & $12 \%$ & $11 \%$ \\
\hline 9 & -15274.00 & -48200.00 & - & 0 & 0 \\
\hline 10 & 302783.14 & 274074.00 & 28709.14 & $9 \%$ & $9 \%$ \\
\hline 11 & 204513.43 & 183920.00 & 20593.43 & $10 \%$ & $9 \%$ \\
\hline 12 & 197325.95 & 171423.00 & 25902.95 & $13 \%$ & $9 \%$ \\
\hline 13 & 527928.98 & 469192.00 & 58736.98 & $11 \%$ & $11 \%$ \\
\hline
\end{tabular}

Source: Own elaboration.

These ratios may be useful to obtain a quantitative measure of the ration between the hope value and the original value at time 0 , and the ratio between the hope value and the value after the transformation.. These ratios may be useful to give a quantitative weight of this part of the value over a longer period of time and in the entire space offering further interesting directions of research. These ratios are relevant for stress testing analysis of the relationship between uncertain events and prices.

The hope value in the fourth column is calculated as the difference between the value at time 0 (reported at time 1) and the value in the current use and at time 1 observing the consequences of refurbishment or:

$$
\mathrm{V}_{\mathrm{H}}=\mathrm{V}_{1}-\mathrm{V}_{0}
$$

The difference indicated in Formula 13 will occur only if the condition exposed in Formula 10 (D'AMATO et al. 2016) is verified. Therefore, a hope value will be possible only if that condition is satisfied and the final result is the difference between the two (in this case) state prices. For the majority of the observations, it is possible to observe a positive hope value except in observation 8. In its case, the costs of the refurbishment are higher than the current value of the property. Therefore, even an increase in the valuation of the property cannot justify the hope value. In the other cases, the difference between the perspective value calculated using binomial modelling gives positive results even if the hope value it is not so relevant compared to the valuation of the refurbished property. The first application of the proposed model provides a method that offers a way of dealing with the basis of value recently proposed by EVS. Using real option theory as a method introduced in the International Valuation Standards makes it possible to deal with uncertain events both in the valuation of land in the valuation process (D'AMATO, 2016) and in the valuation of buildings that may have potential for being refurbished. A perspective change in the legal framework, like the effects of an uncertain event influencing property value, may be quantified using these methods. The proposed methodology may be considered as a quantitative measure of uncertain events useful for property valuation, assessment of worth and market analysis. The proposed methodology may be considered as a quantitative measure of uncertain events useful for property valuation, assessment of worth and market analysis. 


\section{Discussion and conclusions}

In this work, the application of a real option model for the valuation of hope value in the real estate market of Olsztyn has been proposed. Starting from the original model of TITMAN (1985), who applied the real option theory to the valuation of vacant land, the proposed model appraises the hope value of property to be refurbished. Literature on the real option theory may lead to practical application in valuation activity. In this way, uncertain events and their influence on the local real estate market may be measured and quantified. Uncertain legislation or a possible future change in the legislation process may be quantified, and the rationality of the methods relies on a valuation procedure found in the International Standards. It is also possible to distinguish two parts of value in the application of this method, i.e., the former - linked to the market value, and the latter - based on the future value or hope value. These implications may be relevant in the valuation of market value in the mortgage lending process, in the valuation of investment value whose value depends on uncertain contexts.

The practical application shows how the real option may have the potential to become a valuation methodology for solving practical professional valuation problems. On the other hand, International Valuation Standards have considered option pricing methodologies as methods of appraisal since 2011 (IVS 2011).

The foundations of real option theory rely on the assumption of a perfect real estate capital market, although the high transaction costs and the limited divisibility of real property make for the real estate being a long way from such a presumption. Although this limits its application to a limited number of cases, it also shows that this method may have potential in solving real estate market problems. The use of the binomial model is preferred, especially when applied to the direct real estate market. Further directions of research are the analysis of the relationship between current value and hope value described by the two coefficients (primary and perspective value coefficient). A further direction of research is exploring the relationship between sustainability and property valuation with the use of the real option theory. The perspective hope ratio and the primary hope ratio are stress testing methods that may be analyzed both in terms of space and in terms of time.

\section{References}

Black F., SCHOLES M., 1973, The Pricing of Options and Corporate Liabilities, The Journal of Political Economy, 81:3, pp. 637-654.

BuetOW G. W. JR, AlBerT J. D., 1998, The Pricing of Embedded Options Real Estate Lease Contracts, Journal of Real Estate Research, Vol. 15 issue 3, pp. 253-65.

BRENNAN M.J., SCHWARTZ E. S., 1985, Evaluating Natural Resource Investments, Journal of Business, 58, pp. 135-57.

BRUECKNER J. K., ViNTAGE A., 1980, Model of Urban Growth, Journal of Urban Economics, 8, pp 389-402.

CAPOZZA D. R., SICK G.A., 1994, The Risk Structure of Land Markets, Journal of Urban Economics, 35, pp. 297-319.

CAPOZZA D.R., 1990, The Stochastic City, Journal of Urban Economics, 28, pp.187-203.

Clapp J.M., Salavei K.B., 2010, Hedonic Pricing with Redevelopment Options: A New Approach to Estimating Depreciation Effects. Journal of Urban Economics, Vol. 67 issue 3, pp 362-77.

ClapP, J.M., SAlAVEI K.B., WONG S.K., 2012, Empirical Estimation of the Option Premium for Residential Development, Regional Science and Urban Economics, vol. 42 issue 1-2, pp. 240-56.

Clapp, J.M., JOU J., LeE T., 2012, Hedonic Pricing with Redevelopment Options under Uncertainty, Real Estate Economics, 40, pp. 197-216.

Costello G., Leishman C., 2011, Using Option Pricing Theory to Value Development Land, Paper presented at 17 th meeting Pacific Rim Real Estate Society Conference 16-19 January Gold Coast, Australia.

Cox J. C., Ross S. A., RubinsteIN M., 1979, Option Pricing: A Simplified Approach, Journal of Financial Economics, No. 7, pp. 229-263.

CunNingham C.R., 2006, House Price Uncertainty, Timing of Development, and Vacant Land Prices: Evidence for Real Options in Seattle, Journal of Urban Economics 59, pp. 1-31.

European Central Bank, 2014, Asset Quality Review, II Phase Manual.

D'AmAтo M., 2010, A Location Value Response Surface Model for Mass Appraising: An "Iterative" Location Adjustment Factor in Bari, Italy, International Journal of Strategic Property Management, Vol.14, issue 3 pp. 231-244 . 
D'Amato M., Amoruso P., 2016, The Valuation of Hope Value in a Vacant Land Using Real Option Theory, Paper presented at 23rd ERES meeting in Regensburg, Germany.

D'Amato M., KAUKO T., 2012, Sustainability and Risk Premium Estimation in Property Valuation and Assessment of Worth, Building Research and Information, Vol. 40 issue 2 March-April 2012 pp.174185.

D'AmATO M., 2015, Income Approach and Property Market Cycle, International Journal of Strategic Property Management, Vol.29 issue 3, pp. 207-219.

GELTNER D., 1989, On the Use of the Financial Option Price Model to Value and Explain Vacant Land, AEUEA Journal, Vol. 17 issue 2, pp.142-158.

Geltner D., Riddiough T., STOJANOVIC S., 1996, Inside the Effect of Land Use Choice: The Perpetual Option On the Best of Two Underlying Assets, Journal of Urban Economics, 39, pp. 20-50.

GrenadieR S. R., 1995, The Persistence of Real Estate Cycles, Journal of Real Estate Finance and Economics, 10, pp. 95-119.

Grovenstein R.A., J.B. KAU, H.J. MunNeKe, 2011, Development Value: A Real Options Approach Using Empirical Data. Journal of Real Estate Finance and Economics, vol. 43 issue 3, 321-35.

Holland S., OTt S., RidDiough T., 2000, The Role of Uncertainty in Investment: An Examination of Competing Investment Models Using Commercial Real Estate Data, Real Estate Economics, Vol. 28 issue 1 Spring, pp. 33-64.

International Valuation Standards Committee, 2011, International Valuation Standards.

International Valuation Standards Committee, 2013, Valuation Uncertainty, Technical Information Paper n.4

KunTER G.W., SEIFERT J.A., 1989, The Valuation of Mortgage Loan Commitments Using Option Pricing Estimates, Journal of Real Estate Research, Vol. 4 issue 2, pp. 13-20.

MCDONALD R., SIEGEL D., 1986, The Value of Waiting to Invest, The Quarterly Journal of Economics, vol. 101 issue 4, pp. 707-28.

MYERS S., 1977, Determinants of Corporate Borrowing, Journal of Financial Economics, 5, pp. 147-175.

PADDOCK J.L., DANIEL R., SIEGEL E., SMiTH J.L., 1988, Option Valuation of Claims on Real Assets: The case of Offshore Petroleum Leases, Quarterly Journal of Economics, 102, pp. 479-508.

PAtel K., Paxosn D., Foo SING T., 2005, A Review of the Practical Use of Real Property Options, RICS Research Paper Series, Vol. 5 issue 1, April 2005.

RICS, 2012, Financial Viability in Planning, RICS Guidance Note, $1^{\text {st }}$ edition.

QUIGG L., 1993, Empirical Testing of Real Option-Pricing Models, Journal of Finance, Vol. 48 issue 2, pp. 621-640.

RENIGIER-BIŁOZOR M., BIŁOZOR A, WiśNIEWSKI R., 2017, Real Estate Markets Rating Engineering as the Condition of Urban Areas Assessment, Land Use Policy; Vol. 61, February 2017, pp. 511-525.

Titman S., 1985, Urban Land Prices Under Uncertainty, The American Economic Review, Giugno, 75, pp. 505-514.

WomAcK K.S., 2015, Real Options and Urban Land Values, Journal of Real Estate Literature, Vol. 23, issue 1, pp. 53-63.

WHEATON W.C., 1982, Urban Spatial Development with Durable but Replaceable Capital. Journal of Urban Economics, 12, pp. 53-67.

WiLliams J., 1991, Real Estate Development as an Option, Journal of Real Estate Finance and Economics, 4, pp. 191-208.

SOMERVILle C.T., 2001, Permits, Starts, and Completions: Structural Relationships versus Real Options, Real Estate Economics, 29, pp. 161-90.

TiEn Foo SING, 2001, Optimal Timing of a Real Estate Development Under Uncertainty, Journal of Property Investment and Finance, Vol. 19 issue 1, pp. 35-52. 